\title{
Creative Dialogues Between University of Nicosia Fine Art Students and Strovolos III Residents: A Displaced Housing Estate in Nicosia, Cyprus
}

\author{
Diálogos criativos entre estudantes da Escola de Belas \\ Artes de Nicósia e os residentes de Strovolos III: \\ um conjunto habitacional deslocado em Nicósia, Chipre
}

\begin{abstract}
Diálogos creativos entre estudiantes de la Escuela de Bellas Artes de Nicosia y los residentes de Strovolos III: un conjunto de viviendas desplazadas en Nicosia, Chipre
\end{abstract}

Evanthia Tselika *

http://dx.doi.org/10.22409/poiesis.2033.201-216

ABSTRACT: This text concentrates on creative dialogues shaped by fine art students together with elderly residents from Strovolos III, displaced housing estate in Nicosia. Such neighbourhood became the classroom for the module Public Art and Socially Engaged Practices of the Fine Art program of the University of Nicosia in the academic year 2017-2018 in collaboration with Artos Foundation. Students collaborated with the residents of Strovolos III to shape a series of creative mappings and actions.

KEYWORDS: Strovolos III; socially placed art; refugee state housing Cyprus; University of Nicosia Fine Art program; public and socially engaged art course

\footnotetext{
* Evanthia Tselika é doutora, Professora Assistente e Coordenadora do Programa de Belas Artes da Universidade de Nicósia, Chipre. Sua pesquisa é focada na arte contemporânea, no contexto urbano, na transformação de conflitos, processos comunitários e práticas artísticas socialmente engajadas. E-mail: tselika.e@unic.ac.cy
} 
RESUMO: Este texto concentra-se em diálogos criativos construídos por estudantes de belas artes com idosos residentes de Strovolos III, conjunto habitacional deslocado em Nicósia. Este bairro tornou-se a sala de aula para o módulo Arte pública e práticas socialmente engajadas do programa de belas artes da Universidade de Nicosia no ano letivo de 2017-2018, em colaboração com a Artos Foundation. Estudantes colaboraram com os moradores de Strovolos III para formatar uma série de mapeamentos e ações criativas.

PALAVRAS-CHAVE: Strovolos III; arte socialmente articulada; habitação do estado para refugiados em Chipre; Programa de Belas Artes da Universidade de Nicósia; curso de arte pública e socialmente engajada

RESUMEN: Este texto se centra en diálogos creativos construidos por estudiantes de bellas artes con ancianos residentes de Strovolos III, conjunto habitacional desplazado en Nicosia. Este barrio se convirtió en el aula para el módulo Arte público y prácticas socialmente comprometidas del programa de bellas artes de la Universidad de Nicosia en el año escolar de 2017-2018, en colaboración con la Artos Foundation. Los estudiantes colaboraron con los residentes de Strovolos III para dar formato a una serie de asignaciones y acciones creativas.

PALABRAS CLAVE: Strovolos III; arte socialmente articulado; vivienda del estado para refugiados en Chipre; Programa de Bellas Artes de la Universidad de Nicosia; curso de arte público y socialmente comprometido

Como citar: TSELIKA, Evanthia. Creative Dialogues Between University of Nicosia Fine Art Students and Strovolos III Residents: A Displaced Housing Estate in Nicosia, Cyprus. Poiésis, Niterói, v. 20, n. 33, p. 201-216, jan./jun. 2019.

doi: http://dx.doi.org/10.22409/poiesis.2033.201-216

Poiésis, Niterói, v. 20, n. 33, jan./jun. 2019. 


\section{Creative Dialogues Between University of Nicosia Fine Art Students and Strovolos III Residents: A Displaced Housing Estate in Nicosia, Cyprus}

From September 2017 until June 2018 and as part of the European wide Artecitya project, ${ }^{\dagger}$ I worked together with 30 fine art students from the University of Nicosia, in collaboration with Artos Foundation, in a shop the art organisation secured on Palliginisias Square, Strovolos III displaced housing estate in the divided city of Nicosia, Cyprus. The decision to work together with my students was taken largely due to the interviews and conversations I carried out with the residents of the Strovolos III estate, where they repeatedly described the neighbourhood as an "old people's home". It is also not unrelated to previous research and socially engaged practices in relation to these urban neighbourhoods (https://evanthiatselika.files.wordpress.com/2012/01/booklet_no3_digital.pdf) and the fact that it is a phenomenon which I have observed in my own neighbourhood as I also live in one such estate in Nicosia.

\footnotetext{
${ }^{\dagger}$ ARTECITYA - Envisioning the City of Tomorrow (2014-2018) was a Europe-wide project bringing together artists, architects, town planners and citizens. The priority was to stimulate a vigorously innovative approach to the concept of urban life taking into account the sociological evolution and people's needs. Artecitya grouped 8 coorganizers from around Europe devoted to planning and developing towns and cities particularly regarding their architectural and artistic content (https://artosfoundation.org/?project=eu-program-artecitya-en).
} 


\section{The Cypriot displaced state estates}

The urban neighbourhoods of the Cypriot displaced state estates were built to re-house the approximately 200,000 internally displaced Greek Cypriots who were forced to leave their homes in Northern Cyprus during the 1974 war. This low-cost grand state housing project was initially undertaken in 1976 with international aid and with the hope that it would only be a temporary solution following the war. At the start, because there were so many displaced people living in tents, construction was hurried; and urban legend has it that adjusted plans of UK council estates were used. The resettlement of people into this large housing project -with more than fourteen thousand housing units in a country whose population is under one million - was carried out according to income level and the estates were placed on the edges of the city, near industrial areas which could absorb the new influx of workers. Through their placement at the periphery of urban and economic life, the prejudice that accompanied living in them meant that this social group felt labelled by their spatial positioning. In 1997, a political decision was taken and the deeds of the homes were given to their residents by 2005 , transforming the state housing estates from public to private. These "displaced housing projects" are spaces that have become attached to the notion of "internal refugee", even though now they are urban spaces that are increasingly being inhabited by elderly refugees that are slowly passing away, families on very low incomes and migrant families that seek cheap accommodation. I come to this from the position of an arts practitioner, an estate resident and having worked in the conceptualisation and realisation of different art activities in the estates since 2011.

The displaced housing estates found in the South part of Cyprus were constructed hurriedly between the years of 1976 to 2000 and they form the primary example of communitarian architectural environments (of common living) on the island. There are sixty-nine state housing estates and they include low rise blocks of flats and homes. Through this scheme the Cypriot government provided low-cost houses free of charge to "low-income" families, following their displacement from the north of the island. In the period of 1975$1986,12,500$ families found what was meant to be "temporary" housing in such projects. These were comprehensively planned to include basic services such as shopping centres,

Poiésis, Niterói, v. 20, n. 33, jan./jun. 2019. 
community centres, open spaces, schools, play-grounds, medical centres and homes for the elderly. The use of these "common spaces" now-days is minimal. To date, the state has constructed approximately 14,000 housing units which accommodate approximately 60,000 people across the island (Department of Town Planning and Housing). All houses, blocks of flats and communal spaces were constructed with the same basic architectural design, building components and materials; thus, implementing the concept of industrialization within house construction. Repetition of individual components was used in the design, thus facilitating mass production, ensuring low costs and quicker delivery at a time of need. In Cyprus, through the "displaced housing projects", what was being attempted was to find a temporary solution for large numbers of homeless people. (TSELIKA, 2014 [Sinikismoi- Conflict Transformation Art Booklet 3]).

The social theorist Roger Zetter has researched and written in relation to the issue of the "refugees" of the Cyprus Republic after 1974. He presents the contradictory nature of the re-housing of the displaced Cypriots, by indicating that they were integrated in the South part of the island, but, at the same time, they were differentiated because of the characteristics of this state housing programme. Zetter indicates the unique nature of the displaced housing programme, because of its magnitude and its quality. The displaced - or a large number of them - were re-housed in permanent shelter funded by the Cypriot government. Zetter also emphasizes their fiscal integration in the 1980 s and 1990s due to the post destructive rapid economic development that the rebuilding brought to the island. (ZETTER, 1986; 1991; 1998) These built environments of the city are isolated in terms of their presence within the context of the public sphere, but they have an intense public presence as a reminder of war, of ethnic identity and of collective memory. The lack of substantial dialogue in relation to the Cypriot displaced estates, to which the locals refer to as "prosfigikoi sinikismoi" (refugee settlements), became the springboard for carrying out research based on the social narratives of these built environments. The Cypriot state developed these spaces hurriedly and, thus, even used architectural plans for estates that were built in Britain. The hurried nature of this endeavour is presented not only through the swift architectural construction, but also through the fact that they created 
new communities. The state, through its policies, did not re-house the displaced villages and towns together; instead, they separated the uprooted communities, creating new collectivities.

\section{The concretisation of the camp: the internally displaced person and the refugee}

The displaced housing estates constructed by the RoC are directly linked to the image of the refugee camp, an image that has become a regular occurrence in the global media. The experience of displacement for the majority of Greek Cypriots took place in the summer of 1974, resulting in a situation where many people lived in tents for several months. Displacement for the Turkish Cypriot community had begun a decade earlier, when ethnic friction and inter-communal violence pushed large proportions of the community into enclaves.

Zetter indicates that the "refugee housing" in Cyprus "is unlike the stereotyped image in other countries". (1991, p. 42) Forced migration in Cyprus was embodied in the built environment of the RoC through the government's housing policy, which moved the Cypriot "refugees" "rapidly from tents and prefabricated shelter" into "permanent dwellings" within "comprehensively planned estates", located primarily "on the urban periphery". (ZETTER, 1986, p. 108) Writing approximately ten years from the start of the construction of these housing estates, Zetter informs us that the refugees were "being rapidly assimilated into the urban economy in the factory estates springing up near the housing areas". (ZETTER, 1986, p. 109). A very different image is presented approximately forty years later, and the "richly-planted gardens" (ZETTER, 1986, p. 109) that Zetter observed are overgrown and abandoned, as the first generation of residents (displaced persons) is gradually passing away. Their descendants had rejected the refugee label and had chosen to live outside of these urban pockets (should their finances permit it) which exist within the city, but which are also differentiated by it. At present, houses are being renovated and repopulated by the grandchildren of the initial residents or other buyers and renters who, to a large extent, are also migrants.

Poiésis, Niterói, v. 20, n. 33, jan./jun. 2019. 
The "refugee neighbourhoods" in Cyprus are managed by the Department of Town Planning and the Service of Displaced Individuals. There is an ambivalent relationship between the notion of the refugee and the internally displaced person - which is largely reflective of the time period in which the displacement of Greek Cypriots occurred. The discourse in relation to internal displacement has become much more prominent in the last twenty years, as internal conflicts increased during the 1980s and 1990s. (BURN, 2005) The legal definition of the term "refugee", as outlined in the 1951 Convention Relating to the Status of Refugees (UNHCR, 2013), is an individual who due to "a well-founded fear of persecution... is outside of his or her country of nationality". (UNHCR, 2013) What is currently understood as a refugee, however, actually is reflected in much broader terms. As refugee studies' theorists Alexander Betts and Gil Loescher indicate, the "term 'refugee' means different things in different contexts". (2011, p. 5) It includes "people fleeing a range of causes including authoritarian regimes; conflict; human rights violations; large-scale development projects; environmental disasters" (BETTS; LOESCHER, 2011, p. $5)$ and extends to the uprooting of people who are displaced within their country of origin. (BETTS; LOESCHER, 2011, p. 5) Political scientist Emma Haddad also points out and reaffirms this "false dichotomy between 'refugee' and 'internally displaced person". (2008, p. 43) Haddad points out, there is "no conceptual difference between the refugee" (2008, p. 43) and the internally displaced person. Both groups have been subjected to forced migration, although they are differentiated by access to impenetrable "international political boundaries". (HADDAD, 2008, p. 43) This notion is reinforced by Roger Zetter, who points out that Greek-Cypriot refugees are not refugees, since they have not been forced "outside their country of origin" (ZETTER, 1998, p. 308); nevertheless, he continues, they "exist in what UNHCR describes as a 'refugee-like situation' and display the familiar characteristics of refugee populations". (ZETTER, 1998, p. 308)

The displaced Cypriot persons living in the estates were given the deeds to their homes in 2007, thereby transforming the refugee neighbourhoods from state owned property to mostly privately-owned property. The inhabitants of these spaces today and the new communities of these semi state and semi-private environments are mostly displaced eld- 
erly Cypriots and migrants, and this is particularly observed in the Strovolos III neighbourhood. In the collaboration with Artos, a key concern was how the arts can activate these largely forgotten urban environments and facilitate a process of dialogue between the residents and the practices developed in relation to the neighbourhood.

\section{Palliginisias Square and art student actions}

Palliginisias square is the central square with many shops lying empty or providing services to the largely elderly population of the neighbourhood. Artos Foundation, in collaboration with Strovolos Municipality, secured one of the empty shops on the square, which they allowed us to use throughout that academic year. From September 2017 until June 2018 I worked together with 30 fine art students, with the Artos shop in the square acting as our base.

Through a series of visits to the neighbourhood, the fine art students interviewed the residents, visually mapped the neighbourhood and assisted in producing an experimental publication (https://evanthiatselika.files.wordpress.com/2018/10/booklet-lower.pdf) presented at the exhibition Whoever Has a Tree Has Shade, November-December 2017, and at the festival 1 Neighbourhood, 101 Villages (drawn from the number of villages people originated from in Strovolos III), alongside a series of informal actions and interventions that enabled these. The informal and formal actions that took place focused on the voices of the residents, their stories, the decaying-built ecologies of the neighbourhood and an exchange between the students and the residents. It was through this exchange that the actions of the festival were carried out as the students gathered the suggestions of the residents and tried to collaborate in shaping the actions.

A visual sequence from fragments of this process in which students shaped their actions and creative output in collaboration with the residents follows.

Poiésis, Niterói, v. 20, n. 33, jan./jun. 2019. 

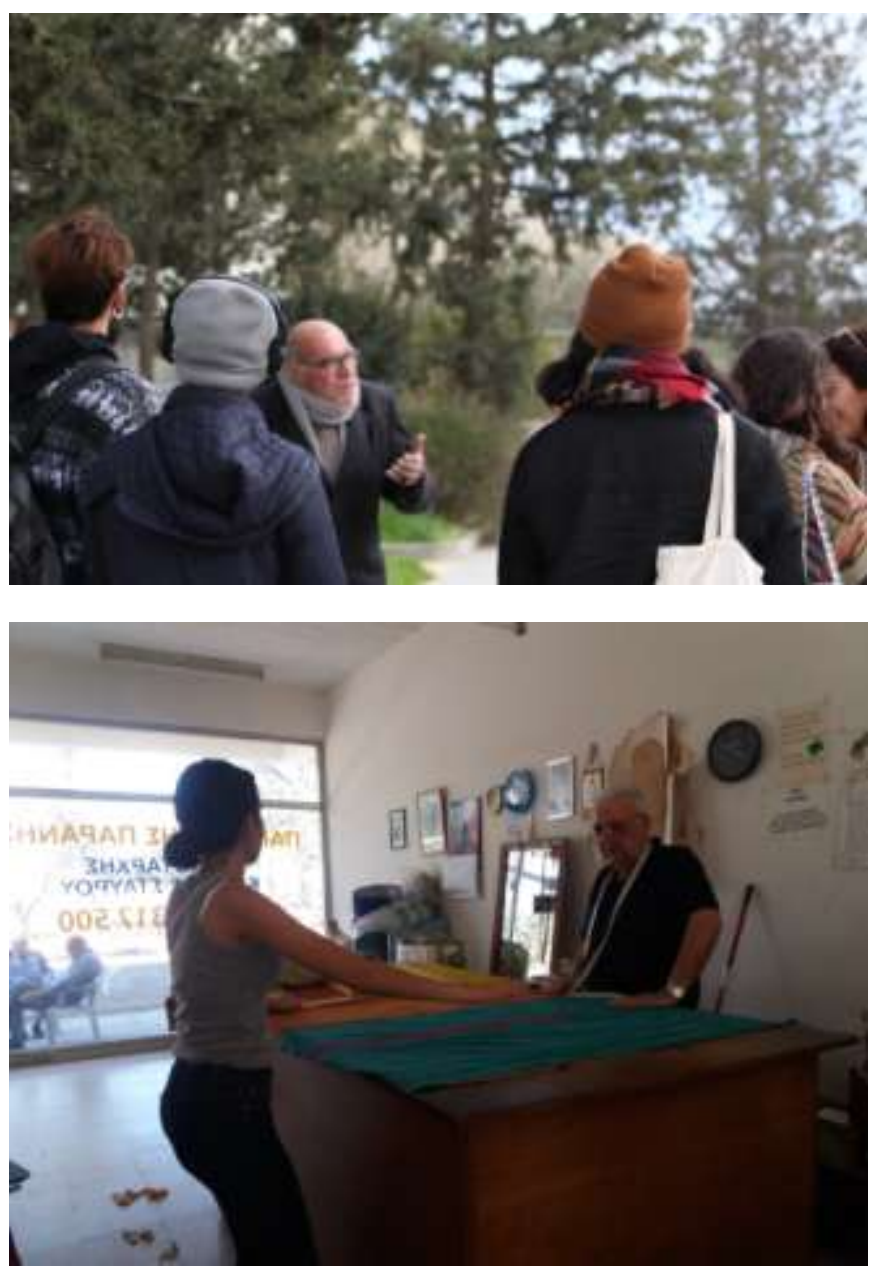

Fig. 1 - The students learning from the estate residents about the neighbourhood. (Photo: Stavri Christou)

Fig. 2 - The neighbourhood officer, Mr Panayiotis Paranis, who is also the neighbourhood tailor, collaborated with Myriam Gatt in producinq a textile art piece. (Photo: Evanthia Tselika) 


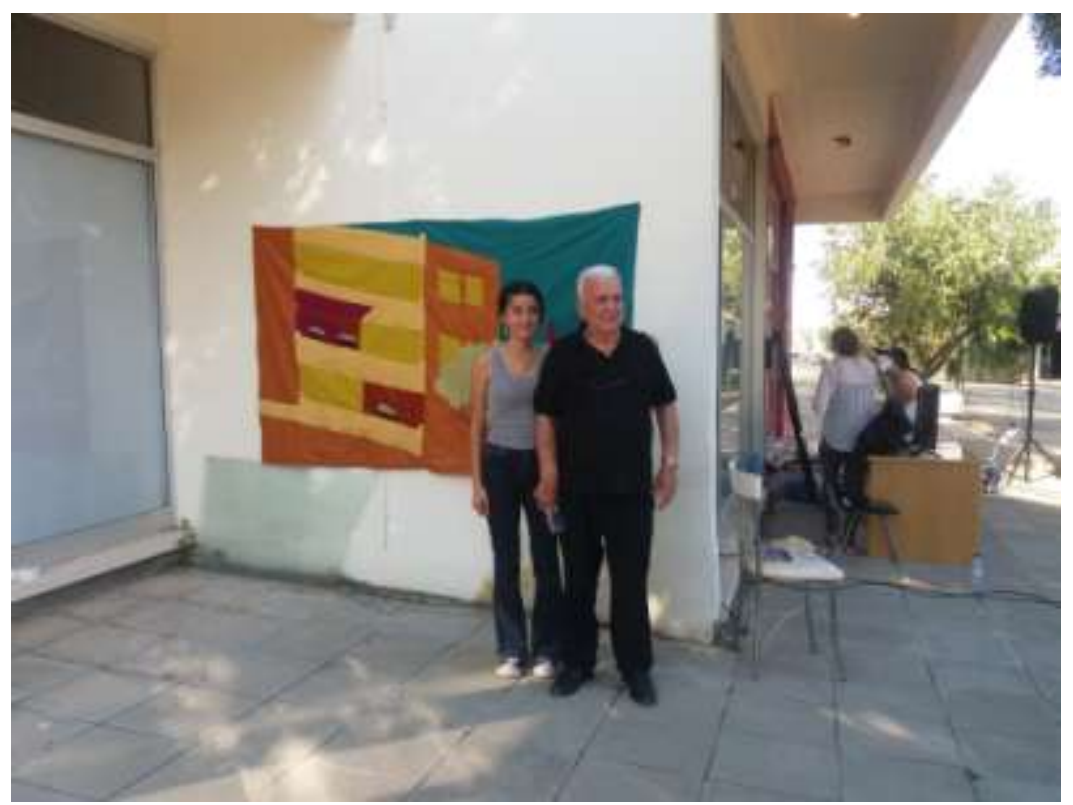

Fig. 3 - The final artwork which was presented at the festival.

(Photo: Evanthia Tselika)

Poiésis, Niterói, v. 20, n. 33, jan./jun. 2019. 


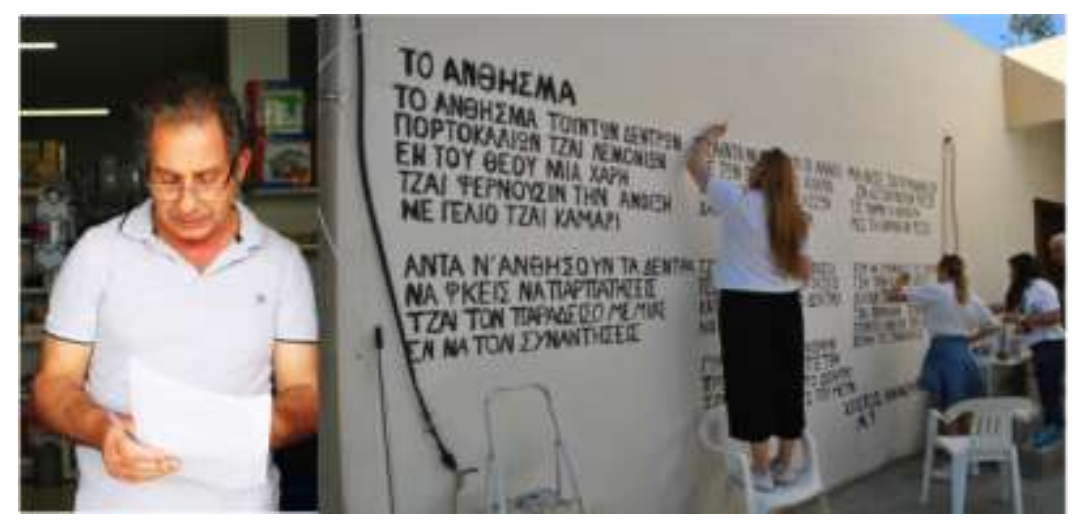

Fig. 4 - Mr Christakis Karaolis, on the left (photo: Phoivi Antoniou), the neighbourhood supermarket owner and poet. Mr Karaolis shared several of his poems with us. One of his poems, titled The Blossoms was painted onto one of the walls of the central square by a group of students. (on the right; photo: Evanthia Tselika) 


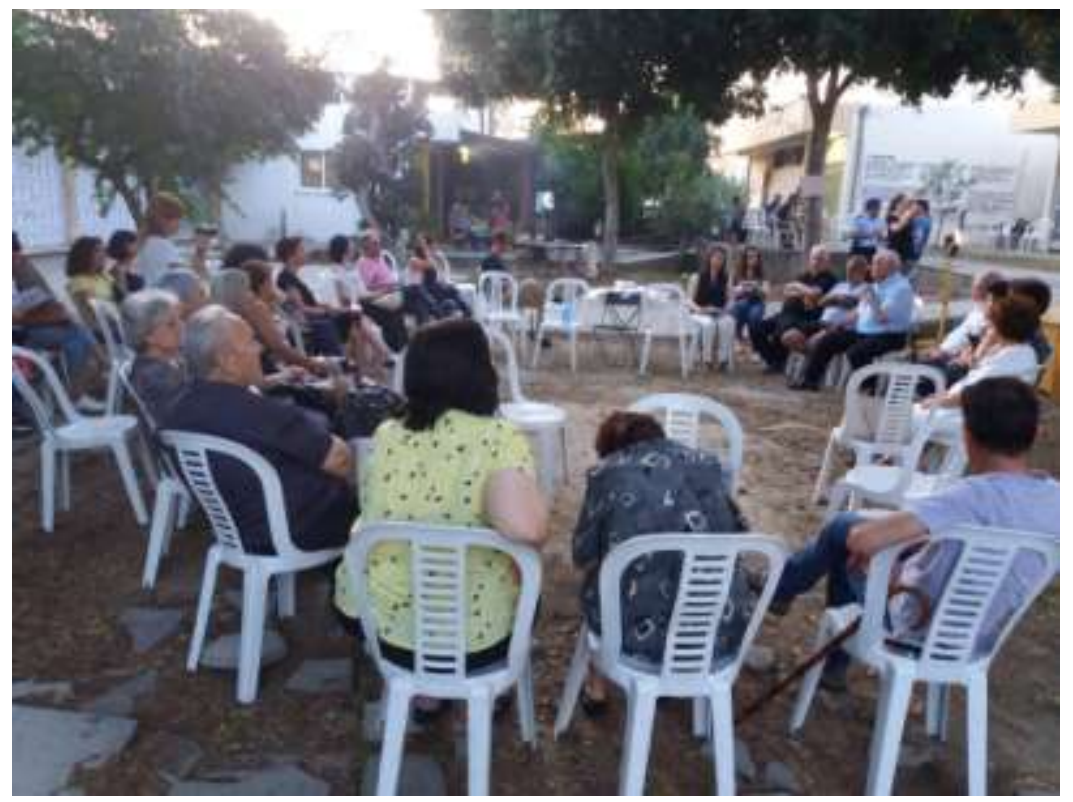

Fig. 5 - Story telling by the residents on the day of the festival facilitated by student Phoivi Antoiniou. (Photo: Evanthia Tselika)

Poiésis, Niterói, v. 20, n. 33, jan./jun. 2019. 
Phoivi Antoniou collaborated with the residents both to present a series of photographic portraits and fragments of interviews that she carried out with the residents, as well as a collective circle of story sharing by the residents on the day of the festival. The title of the festival was in fact drawn from Phoivi's research and her interviews with the residents and local representatives.

Bringing together the students and the residents, through the umbrella shaped by the platform that Artos enabled by providing us access to the shop front they secured, allowed for a context of dialogue and exchange between the students and the residents to be formed. Dialogue presents a key feature of debates that relate to the participatory and socially engaged dimension of contemporary artistic practices that work together with communities. (KESTER, 2004) Within the framework of this collaboration with Artos, a creative dialogue between the students and the residents of the estate presents one of the central elements of my input in this project, insofar as the dialogical practice becomes a vehicle through which relationships between different social groups are facilitated and an increased debate on particular socio-political conditions.

Bacon, Yuen and Korza (in an arts research report drafted for Animating Democracy) analyze the nature of "artistic activity that stimulates civic dialogue" (1999, p. 38), through the "wide range of aesthetics, artistic approaches, and issues", that "artists and institutions have embraced" (BACON; YUEN; KORZA, 1999, p. 38) when engaged in civic dialogue arts practice. Some of the dimensions of "arts-based civic dialogue projects" are the "aesthetic possibilities afforded by the social and political variables of civic context", the "multiple goals" that "drive a project" and "dialogue". (BACON; YUEN; KORZA, 1999, p. 39)

There are diverse reasons why art institutions and practitioners undertake "civic dialogue" projects which implicate artistic practice with engaging more people in the process of civic dialogues and civic action: 
- The engagement of "new and more varied audiences" through "community discussion formats" which are used to interest and educate audiences about the form, process, and content of art. (BACON; YUEN; KORZA, 1999, p. 39)

- Facilitating "intergroup communication", taking into account the assumption that the arts depict the ability to act as "a bridge or platform from which to explore both the differences between and common experiences of or between different cultures, classes, and groups". (BACON; YUEN; KORZA, 1999, p. 39)

- That civic dialogue that is fostered through the arts can "raise awareness about an issue". (BACON; YUEN; KORZA, 1999, p. 40)

In the case of the students' collaboration with the residents and the manifestation of a series of informal and formal actions that shaped this process of exchange, this would not have been possible without the shop/platform provided by the art centre and its collaboration with the Department of Housing and Town Planning and the Municipality of Strovolos. Through this complex and layered network of a local authorities body, an art centre and a university, there was a more varied base of participation involved in the form, process and content of artistic production, facilitating inter-group communication which focused on raising awareness around the stories of the people who live and work in the displaced housing neighbourhoods. 


\section{Instead of a conclusion}

\section{The Blossoms by Christakis Karaolis, Strovolos III}

The orange and lemon tree blossoms

Are God's blessing

They herald spring

With laughter and pride

When they are in bloom

Take a walk

And in a moment

You will encounter heaven

And when the blossoms' scent mixes

With the cry of the birds

And the buzzing of the bees

Oh what a joy!

And when you've walked enough

And are filled with the smells

Sit under a tree

And rest

With your body on the ground

And a stone for a pillow

Look up to the tree

And count the blossoms

Also close your eyes

And let your mind escape

And beloved Morfou*

Will shine in your heart

And when you wake

Before the sun sets

Turn up again

And plead that this dream you had

Will come to you again

* Village now in occupied Cyprus, renowned for its orange and lemon trees. 


\section{References}

BACON, B. S.; YUEN, C.; KORZA, P. Animating Democracy: The Artistic Imagination as a Force in Civic Dialogue. Washington, DC: Americans for the Arts, 1999.

BETTS, A; LOESCHER G. (Ed.). Refugees in International Relations. London; New York: Oxford University Press, 2011.

BURN, C. Report: Internal Displacement, 2005. Available: http://www.forcedmigration. org/research-resources/expert-guides/internal-displacement/alldocuments.

HADDAD, E. The Refugee in International Society: Between Sovereigns. Cambridge; New York: Cambridge University Press, 2008.

KESTER, Grant. Conversation Pieces: Community and Communication in Modern Art. Berkeley; London: University of California Press, 2004.

TSELIKA, E. Sinikismoi - Conflict Transformation Art Booklet 3. PhD Conflict Transformation Art, Birkbeck University of London, 2015. Available: https://evanthiatselika.files. wordpress.com/2012/01/booklet_no3_digital.pdf.

UNHCR (United Nations High Commisioner for Refugees). Convention and Protocol Relating to the Status of Refugees, 1951, 2013. Available at: http://www.unhcr.org/3b66c2aa10.html.

ZETTER, R. Rehousing the Greek-Cypriot Refugees from 1974: Assimilation, Dependency and Politirizalion. In KOUMOULIDES, J. (Ed.). Cyprus in Transition 1960-1985. London: Trigraph, 1986, pp. 106-125.

ZETTER, R. Labelling Refugees: Forming and Transforming a Bureaucratic Identity. Journal of Refugee Studies, v. 4, n. 1, pp. 39-62, 1991.

ZETTER, R. We are Strangers Here - Continuity, Transition and the Impact of Protracted Exile on the Greek-Cypriot Refugees. In CALOTYCHOS, V. (Ed). Cyprus and Its People: Nation, Identity and Experience in an Unimaginable Community (1955-1997). Boulder, Colorado: Westview Press, 1998.

Poiésis, Niterói, v. 20, n. 33, jan./jun. 2019. 